\title{
HERETICS AND CDLDNIZERS
}





\section{HERETICS AND CDLDNIZERS}

FORGING-RUSSIA'S-EMPIRE-IN-THE SOUTH-CAUCASUS

NICHOLAS B. BREYFGGLE 


\section{Copyright $(2005$ by Cornell University}

All rights reserved. Except for brief quotations in a review, this book, or parts thereof, must not be reproduced in any form without permission in writing from the publisher. For information, address Cornell University Press, Sage House, $5_{1} 2$ East State Street, Ithaca, New York 1485 o.

First published 2005 by Cornell University Press

Printed in the United States of America

Library of Congress Cataloging-in-Publication Data

Breyfogle, Nicholas B., $1968-$

Heretics and colonizers : forging Russia's empire in the south Caucasus / Nicholas B. Breyfogle.

p. $\mathrm{cm}$.

Includes bibliographical references and index.

ISBN o-8014-4242-7 (cloth : alk. paper)

1. Transcaucasia-History-19th century. 2. Land settlementTranscaucasia. 3. Transcaucasia-Ethnic relations. 4. Dissenters, Religious-Transcaucasia. I. Title.

$\mathrm{DK}_{5}$ 09.B6866 2005

$947.5^{\mathrm{O}} 7$ - dc2 2

2004019431

Cornell University Press strives to use environmentally responsible suppliers and materials to the fullest extent possible in the publishing of its books. Such materials include vegetable-based, low-VOC inks and acid-free papers that are recycled, totally chlorine-free, or partly composed of nonwood fibers. For further information, visit our website at www.cornellpress.cornell.edu.

Cloth printing 10987654321 
For Jillian and Charlie

"Find a road and we will travel" 
